\title{
Cold War Spaces: Tinker Tailor Soldier Spy in television and cinema
}

\section{Dr. Douglas McNaughton, University of BrightonD.McNaughton@brighton.ac.uk}

\begin{abstract}
This article examines two adaptations of John le Carré's 1974 novel Tinker, Tailor, Soldier, Spy, the 1979 BBC television serial and the 2011 cinema film, in order to investigate critical orthodoxies around the aesthetics of television and cinema. It examines the dialectical relationship between space and place, concluding that filming location acts as a 'framing place', shaping production practices and effecting a dialogic interchange between production space and narrative place. Drawing on original research interviews with production team members, it illuminates the process of production and demonstrates the interaction between material space and social space in the interaction of location and practitioners. The article concludes that the television serial's mimetic fidelity to its source novel results in a text which is at times more 'cinematic' than the cinema version. The cinema film features a more fully developed visual concept throughout its aesthetic, in the motif of the cages, grids, and boxes. However, in its narrative compression and unsubtle use of signifiers of place, the cinema adaptation is at times less 'cinematic' than the television serial.
\end{abstract}

\section{Keywords}

Tinker Tailor Soldier Spy; BBC; 16mm film; John le Carré; Smiley; aesthetics; space and place; spy; location; televisual; cinematic

\section{Introduction}

In the making of screen drama, production space generates narrative place. As Jonathan Bignell has noted, 'when a programme takes place, important aspects of its signification include how it uses the resources of the place where it was made, and how it represents space and place for the viewer on the space of the screen' (2010: 53). This article compares two adaptations of John Le Carré's 1974 Cold War novel Tinker, Tailor, Soldier, Spy in order to examine how 
production space makes narrative place, and how visual style relates to narrative and theme. The case studies are the 1979 BBC serial directed by John Irvin, and the 2011 cinema version directed by Tomas Alfredson. The article investigates how location acts as a 'framing place' (Dovey 1999), shaping production practices and effecting a dialogic interchange between production space and narrative place. It also considers how the productions construct Cold War spaces onscreen using conventionalised 'discourses of place' to give meaning to space turning site into sight through the 'Iron Curtain discursive unconscious'.

These case studies raise issues of medium specificity. Until recently, critical orthodoxies around $20^{\text {th }}$ century television considered it a medium of limited visual appeal, incapable of the spectacle of cinema (Williams 1974). Cinema is assumed to be visual, while television is aural, driven by dialogue (Ellis 1992). In this model, television drama's key site is Raymond Williams' (1968) 'dramatic room' (Wheatley 2005), with an aesthetic of the facial close-up or ‘intimate screen’ (Jacobs 2000). Only recently has television’s aesthetic advanced to approach that of cinema with an 'enhanced visual style' (Nelson 2007: 11). Brett Mills problematizes the televisual/cinematic divide, but acknowledges that in many critical accounts the cinematic 'prioritizes the visual more than what is assumed to be typical for television' (2013: 58). Helen Wheatley argues that medium essentialism has been overdetermined and that televisual spectacle has been critically underexplored (2016: 2). Wheatley acknowledges that television has increased its emphasis on spectacle and visual pleasure in the digital age (5), but rejects the notion that spectacle is inherently 'cinematic' (7). While these accounts complicate medium essentialisms, and while the cinema 'gaze' and the televisual 'glance' (Ellis 1992) may be overly simplistic binaries, it is the case that the aesthetic of much 1970s television has been critically defined (and found wanting) in opposition to the 'cinematic'. This article 
therefore examines the two adaptations of Tinker, Tailor, Soldier, Spy to investigate and compare the aesthetics of cinema and television.

After summarising the novel's plot, its themes, and its social and historical context, the article first compares the televisual and cinematic representations of the 'Circus', the Secret Service headquarters, and how these reflect the theme of post-imperial decline. It then compares the televisual and cinematic representations of Eastern Europe and postulates that both deploy the 'Iron Curtain discursive unconscious'. It then moves to analysis of how production space becomes narrative place in these productions, and how those narrative places connect with visual style in the use of motifs of cages, grids, boxes, and dramatic rooms. The article concludes that the television serial's mimetic fidelity to its source novel results in a text which is at times more 'cinematic' than the cinema version, while both adaptations, in different ways, construct dramatic sites of paranoia, surveillance, oppression, and entrapment.

\section{Cold War Contexts and Landscapes}

John le Carré's Tinker, Tailor, Soldier, Spy (hereafter TTSS) concerns the British Secret Service (the 'Circus') of the 1970s. The book follows the hunt for a spy (or 'mole') in the Service, and retired spymaster George Smiley's attempts to find him. The spy is responsible for an ambush in Czechoslovakia which almost kills British agent Jim Prideaux, and this event is tied to the disappearance of a Soviet agent in Hong Kong (Lisbon on television, Budapest in the film). 
Smiley interviews former members of the Secret Service and pieces the mole's identity together, unmasking him in a safe house as he meets his Soviet contact. Prideaux kills the mole, his best friend Bill Haydon.

The novel reflects a sense of national decline and paranoia. For Britain, the 1970s constituted a decade of instability involving the oil crisis, miners' strikes, the north-south divide, race relations, the Northern Ireland Troubles, and second wave feminism. Even at the time, the British were aware of a sense of crisis, 'a fragmenting socio-cultural landscape' (Newland 2010: 11-12). For Barton (2008), the 1970s spy thriller offers an engagement with issues of identity, national decline, and paranoia, exploring 'the cracks in the social fabric occasioned by the end of imperialism... and the shifting definitions of national identity that accompany social and historical change' (46). The Cold War continued to generate fears of communist infiltrators and double agents, and le Carré's novel reflects the real-life betrayal by the Cambridge spies, Burgess, Philby and Maclean in the 1950s and 1960s. Willmetts and Moran note how the Cambridge spies called into question 'a number of core tropes of British national identity: patriotism, class, sexuality and imperial decline' (2013: 52). Murphy (2012) calls the drabness of the le Carré film adaptations of the 1960s 'a pessimistic antidote to the James Bond films' (216).

These 'state of the nation' qualities are confirmed by the serial's producer Jonathan Powell: 'it was a thriller which had claims on being an important novel because I thought it was about more than spies. I thought it was about a sort of elegy for empire' (Powell 2009). In Powell's view, this engagement with national identity and post-imperial decline justified the then-unusual decision to shoot the serial entirely on $16 \mathrm{~mm}$ film, rather than on videotape in the electronic studio. Oldham (2013: 732) explains the historical context, where film had been used 
for 1960s action-adventure series and 1970s police series, and now began to be used in the production of prestige drama. Powell recalls: 'we were told to make it in the studio. I had no intention of making it in the studio. I didn't know what I was going to do about it [...] I can remember doing seven different budgets. Nobody wanted to let us out' (Powell 2009).

Co-production funding and the casting of Alec Guinness were key to producing the serial on film. Director John Irvin recalls the implications for the serial's co-production funding: 'they promised Guinness to Paramount, who at that point were going to be the partners, without actually signing him [...] so I was under a lot of pressure' (Cinema North West 2011). Powell drafted letters for Le Carré to send to Guinness, ${ }^{1}$ but achieving production on film was a result of internal politics within the BBC itself. Powell explains: 'when Alec Guinness agreed I rang his agent and I said Dennis, it would help me a lot if you could tell the $\mathrm{BBC}$ that Alec would only agree to this if they do it on film. And that was how I got it onto film' (Powell 2009). Guinness's involvement thus gave Powell leverage in negotiating the material conditions of production for the serial, suggesting that the actor's association with cinema may have been a factor in the use of film, despite resistance. 'I was able to say to everybody, well, do you want Alec Guinness or do you not want him, I'm afraid that's the deal [...] it was a real institutional battle' (Powell 2009). Location shooting on film was to be vital in achieving the production's sense of place, beginning with the Circus - the Secret Service headquarters.

\section{The Televisual Circus}

The television serial opens with a pre-titles sequence showing a high-angle exterior shot of Cambridge Circus, a slightly seedy part of London near Soho, and Le Carré's location for his fictional Secret Service headquarters. This establishing shot of the narrative's geographical and 
ideological core is followed by an interior scene showing the Circus heads assembling in a committee room. Deyo (2017) argues that this shot is crucial to establishing the serial's mood of subterfuge and secrecy (9). The high angle wide shot of the Circus building is a narrativised composition, implying that the institution is under covert observation and establishing the theme of surveillance. The nominative connection of the Circus with Cambridge University reflects the book's preoccupation with the class structures of the British Establishment. Cambridge Circus also had associations with Marxism and Russian politics thanks to the presence then of Colletts radical bookshop on nearby Charing Cross Road (Eaden 2002: 38). From his time with the secret service, Le Carré recalls that the Service inhabited 'suites of dusky little rooms'. Le Carré also mentions the institution's nostalgic, introverted nature, whereby personnel were defined by their Second World War exploits: '[i]t stank of war nostalgia.' ${ }^{2}$ The shabby office interiors used on location are redolent of post-imperial decline and blinkered introspection.

While the use of location interiors creates an oppressively bureaucratic feel, it is not without technical challenges. TTSS film cameraman ${ }^{3}$ Tony Pierce-Roberts recalls shooting interiors on location:

[I]n those days film stocks were pretty, pretty slow. So what you would do is you'd put tracing paper on the window. You'd put all your lights outside [...] and the camera was right at the furthest, as far back in the room you could possibly get, on the longest lens you could possibly get $[\ldots]$ and any movement just came from having to pan the camera with the actor. (PierceRoberts 2010a)

The long lens compresses distance and defocuses distracting backgrounds (Millerson 1979: 3640) and this approach seems to aim at generating a claustrophobic interiority. Seen from inside, the blank windows of the Circus offer no view of the outside world, suggesting the extent to 
which the Circus, with its internal politics and arcane language of 'tradecraft', is enclosed and insular. For director John Irvin, the interiority of the Circus is key to the narrative, as he employs a spatial metaphor to describe his approach to the serial: 'I saw my version as [...] a labyrinth, with a very dark secret in the center of it' (NPR 2011). The diegetic setting therefore becomes a metaphor for narrative complexity, and the mise-en-abyme of corridors reflects the maze-like intellectual journey on which Smiley must embark ${ }^{4}$.

Irvin also implies parallels between the BBC, the Circus, and Prideaux's boarding school:

I based my version on the corridors of the BBC [...] This Circus, it was a combination in my imagination really of all the intrigues, jealousies, rivalries within the departments of the $\mathrm{BBC}$ and combined with my schoolmasters, my boarding school. (NPR 2011)

The sequence therefore demonstrates the importance of settings for exploring architectural expressions of ideological state apparatuses reproducing particular ideologies of the British Establishment. According to Tony Pierce-Roberts, some office interiors were filmed on BBC premises, and the Nursery facility scenes in episode seven used the BBC's Engineering Training Centre at Wood Norton in Worcestershire. It is tempting therefore to relate the inward-looking, panoptic Circus interiors to the institutional corridors of the BBC. Jonathan Powell confirms the parallel: 'it was also about the BBC [...] about what lengths does an institution have to do (sic) to survive in a changing political climate. That was what the metaphor was' (Powell 2009). Location filming therefore conveys that espionage is a 'dreary and quotidian affair' (Deyo: 8), bound up in bureaucracy.

The establishing shot of Cambridge Circus is followed by an interior sequence beginning on the closed door of a committee room, seen from inside as the Circus heads individually enter through the door left of frame and walk to the committee table. A new shot 
begins with the entrance of each character, and each character displays a range of performative signifiers. Toby Esterhase (Bernard Hepton) checks an old-fashioned pocket watch. Roy Bland (Terence Rigby) enters reading his committee papers. Percy Alleline (Michael Aldridge) pointedly glances at an empty chair. Bill Haydon (Ian Richardson) enters balancing a saucer on a cup, and kicks the door not quite shut; Esterhase closes it. The scene ends on a shot symmetrically framed along the Z-axis of the table with Alleline centre frame upstage, signifying seniority, and the others ranged down the sides of the table. Alleline strikes a match, lights his pipe, waves the match out ostentatiously, and strips a rubber band from around his files. He speaks. 'Right. We shall start.' The titles run.

Joseph Oldham argues that this scene has no narrative function and that 'its main purpose appears to be establishing the muted, understated and even dreary tone of the serial... a drama of conversation in enclosed spaces rather than one of action and excitement' (2013: 737). The significance of this approach is its reliance on the 'dramatic room'. While filmed on location, each character is introduced with shots on the door which allow them to enter individually, akin to a stage entrance, using the committee room as a three-wall set. The scene lasts almost two minutes, with a single line of dialogue, and visually establishes their personalities and characterisations - the prim Esterhase, the slovenly Bland, the pompous Alleline, the irreverent Haydon. These characters, it later transpires, are the four suspected of being the 'mole'. The details of dress and performance evoking character require careful observation and interpretation more akin to the cinematic 'gaze' than the televisual 'glance' (Ellis 1992). There are tensions evident in this sequence then, between the potential 'cinematic' of film as a medium, and the 'televisual' of performative detail (Caughie 2000: 221). Even shot on film, this sequence conforms to the conventions of studio drama and the 'dramatic room'. 


\section{The Cinematic Circus}

The television serial uses Cambridge Circus as specified in the novel, but the cinema version is less faithful. Geoffrey Nowell-Smith discusses the 'ontological link between nominal setting and actual location' (2001: 103), that is, the auratic power in the use of a location representing itself, which would be impossible to reproduce through a studio replica or a physically similar but inauthentic location. However, Brunsdon (2007a) argues that 'cinematic place has no necessary relationship to location shooting, although location shooting... may offer particular qualities to the mise en scène' (166). Creative labour can construct an imagined diegesis which overrides any claims to realism. Thus, inauthentic sets or locations may provide more interesting dramatic spaces than authentic locations (ibid.). While the television serial's use of Cambridge Circus demonstrates this 'ontological link', the cinema film uses a different space to represent the Circus.

The cinematic Circus exterior was filmed at Blythe House in London's West Kensington, rendering the Circus nickname meaningless. Built between 1899 and 1903, the building is now part of another British state institution, the Victoria and Albert Museum. This choice therefore demonstrates the tension between Nowell-Smith's ontological link, and Brunsdon's imagined diegesis, suggesting that the film's fidelity to the novel is less important than a sense of visual spectacle, giving the cinematic Circus a touristic 'constructed authenticity' (MacCannell 1999) meeting the expectations of international audiences. The Circus is introduced via a low-angle tilt as a red London bus passes in the foreground, the shot composition conveying the idea of concealment and revelation as the bus reveals the Circus. The red bus is an archetypal metonym of 'London discourse' (Brunsdon 2007a), and establishes a clear geographical location. 
The film later presents spectacular overhead shots of the modernist Circus building, digitally added inside Blythe House's inner quadrangle. Director Alfredson comments that the Circus is a 'combination of new and old. This building that's in the centre is a digital construction' (2011). This shot provides a visual metaphor for the Secret Service; the Victorian exterior, in an imposing low-angle shot, suggests normative visual discourses of British Imperialism, while the concealed Circus building is redolent of soulless, repressive bureaucracy. Its drab functionalism is also reminiscent of Brutalist Soviet architecture associated with Eastern Europe (Crowley and Pavitt 2008), implicitly paralleling the Circus and its Russian counterpart. Its mise-en-abyme of frames within frames evokes Churchill's description of Russia: 'a riddle, wrapped in a mystery, inside an enigma' (1939). It is therefore an architectural metaphor for the Soviet mole at the heart of the Circus, and the Victorian façade enclosing concrete modernism visually realises themes of concealment and deception.

The boxes-within-boxes motif is continued in the Circus interiors. These were shot in Inglis Barracks in north London, presenting an open-plan, multi-level space containing office modules lined with orange soundproofing material. These rooms-within-rooms signify secrecy, paranoia, and insularity. While Mark Fisher feels that the film is missing 'the grain of the 1970s' (2011: 41), orange and brown form a key part of the film's mise-en-scène, creating a hyperreal '1970s theme park' (ibid.) based in reproducing prevailing popular discourses of the decade's aesthetic. Eric J. Morgan comments that the film 'evokes that analog world via saturated colors of gray, brown, and burnt orange, all designed to capture the depressed nature of the 1970s. The British Empire is depicted as literally rusting' (Morgan 2016: 95). The orange soundproofed modules have a further metaphoric function, as David Bordwell (2012) points out. The film shows Control's suspected mole through photos taped to chessmen. Bordwell 
links the internal texture of the soundproofed modules with the chess piece motif, connecting mise-en-scène with theme and narrative: 'the chess pieces visualize the multiple-choice problem [...] More broadly, the imagery (with the briefing room as a gridded checkerboard) reminds us that spying, known for decades as The Great Game, is now a global chess match' (Bordwell 2012). Alfredson comments: 'the reality was like long closed corridors, but I thought it wasn't very cinematic to depict long closed corridors so that's a complete fake, the open landscape thing, with the cubes' (Alfredson 2011). This connects choice of location with aspiration to a cinematic sense of scale, and confirms Brunsdon's (2007a) point about the effectiveness of authentic locations versus imagined spaces.

The barracks location connotes militarism and the space's openness offers visual counterpoint to the claustrophobic paranoia of the Circus. In terms of the semiotics of space, open spaces can be as disciplinary as confined ones: '[t]he deterministic conflation of physical enclosure with social constraint, or of open space with liberty, is a dangerous move. An open [spatial] syntax can operate as a powerful signifier of solidarity and democracy in the absence of the practice' (Dovey 1999: 24). The television serial's 'labyrinth' of corridors is contrasted by Alfredson's 'cinematic' barracks, suggesting that it is dramatic space's scale which differentiates the two media. That said, the panoptic cinematic Circus functions as a constraining dramatic room, containing further rooms in the form of the soundproof modules. This space therefore has a further metaphoric function, its rooms-within-rooms again paralleling the mise-en-abyme motif of Russian matryoshka dolls referenced in the novel (381) and used in the television serial's titles to signify the mole's hidden identity.

\section{Places on the Margin: Behind the Iron Curtain}


While scale might seem a signifier of the cinematic, there are sequences in the film which are greatly compressed, temporally and geographically, compared with the television serial's more faithful rendition of the book. This article now compares the television and cinema representations of the novel's Eastern European settings.

Understandings of place and national identity can be reduced to a few basic historically and culturally contingent signifiers (Shields 1991). For example, Colin McArthur (2003) argues that Scotland is internationally recognised through the Scottish discursive unconscious, a narrow range of signifiers including lochs, mists and castles. Similarly, Cold War Eastern Europe had a stable cultural identity at the time of the serial's production. This semiotic core revolves around an iconographic shorthand of checkpoints, blockhouses, watchtowers, Eastern European cars, pine forests and urban wastelands; liminal boundary sites reflecting the Cold War's border crossings and moral ambiguities. This place-discourse can be seen in cinema films such as the Le Carré adaptation The Spy Who Came In From The Cold (1965) and could be called, after McArthur, the Iron Curtain discursive unconscious.

In the novel, Prideaux arrives at Prague airport and proceeds to Masaryk station and Wenceslas Square shopping arcade (Le Carré 1999: 298). Realising he is being followed by agents, he boards a train to Brno, and eludes his followers in the 'one store in Brno main square that sells everything' (ibid.: 299). Escaping through a fire exit, he squeezes onto a crowded tram and meets his contact in a parked Fiat. They drive through a forest track to a hut where they are ambushed with exploding flares, tracer, and soldiers: 'as Jim raced the Fiat down the track he had the impression of leaving a military tattoo at its climax' (ibid., 302). Despite some compression and combination of places, the television version of the Czechoslovakia mission follows the novel with striking fidelity. Geographical models of core and periphery suggest a 
structure of physical and ideological cores surrounded by shifting, hostile foreign peripheries, marginal contested sites (Shils 1975, Lash and Urry 1994, Urry 1995), with pre-Glasnost Eastern Europe firmly situated on the periphery in the 1970s Western imaginary. Prideaux's (Ian Bannen) Brno trip draws on a variety of techniques in constructing a coherent dramatic journey.

The geo-political climate in the 1970s meant that filming behind the Iron Curtain was problematic, and other geographical peripheries supplemented this discourse of place. According to cameraman Tony Pierce-Roberts:

Most of the Czech sequence we shot in Glasgow. Austen Spriggs the designer had been to the Czech Republic and taken lots of stills - for which he got arrested - and lots of posters and things like that, you know, the sort of things that tourists wouldn't be doing, because of course it was still a Communist regime at that point. (2010a)

Spriggs' hazardous experience illustrates the tensions between crew, location, and consumption of place in screen production. When Spriggs returned to Britain, the fruits of his research were used to dress a 'not-very-appealing part of Glasgow which probably doesn't exist any more' (Pierce-Roberts 2010a), 'framing' landscape both visually and ideologically.

Asyndeton in grammar is the joining of words without conjunctions, and Czechoslovakia is therefore presented as an asyndetic site combining location filming in Eastern Europe and Scotland. Prideaux's journey begins with a shot of his face through a car windscreen as a foreground security barrier rises out of frame. A long shot showing a red-roofed house and Mobil garage signifies generalised Central Europe-ness, intercut with point-of-view shots of the empty road and close-ups of Prideaux's face. In part, these shots are determined by practical necessities: 
in their [the BBC's] classic way they'd picked a lot of actors who were supposed to drive and of course couldn't drive [...] so we had to shoot a lot of [background] plates, so went to the Czech Republic to shoot some plates [...] because funnily enough they didn't mind me shooting the backs of cars and things like that. (Pierce-Roberts 2010a)

The space constructed here is asyndetic, combining long shots of the car filmed in Czechoslovakia, and checkpoint shots filmed in Glasgow. Advertising hoardings framing the checkpoint site create an enclosed space, making the open road seem confined. The Czech language hoardings also function as signifiers of geographical verisimilitude.

Prideaux's journey is conveyed by a physically static, geographically enclosed scene in the checkpoint queue. Space is converted into time. While Prideaux waits for his passport, a montage of shots represents time passing, such as a watchtower, a repeat establishing shot seeming to restart the scene, and a shot of Prideaux waking up. An abrupt cut to a frontal shot of Prideaux, with a lorry visible behind and sudden engine noise on the soundtrack, conveys that the shots are discontinuous, and the framing of the looming lorry establishes an edge of menace. Filmed from outside the car, Prideaux is trapped behind the windscreen; the car is liminal, simultaneously a place and a non-place. The end of the sequence is shot from within the checkpoint office. As Prideaux drives off frame left, the shot pulls focus to a venetian blind in the foreground, and a black-leather-gloved hand (a clichéd signifier of repressive state surveillance) pulls down a slat of the blind. This point-of-view shot denotes that Prideaux is being observed. Prideaux is trapped within a variety of frames - windscreens, checkpoint office windows, the checkpoint's physical walls - visually foreshadowing the trap closing around him. He is distanced from the audience by various intradiegetic barriers - checkpoint gates, windscreens, venetian blinds - which leave him confined and isolated. 
When Prideaux reaches Brno, his car arrives on a piece of wasteland; a 'non-place' of failed modernity (Augé 1995) with drab social housing blocks in the background, suitable to substitute for a Soviet state. A large sign reads 'Lachema Brno', ${ }^{5}$ linguistic signifiers again anchoring sense of place, and the foreground of the shot is filled with waste ground. For Brunsdon, such spaces are empty 'of narrative. They are immanent: spaces in which something might happen' (2007b: 228). The empty space of the deserted road and the 'non-place' wasteland is matched by the slowness of the narrative, combining to build atmosphere and tension, while the cut to a high shot again evokes the theme of surveillance. The sequence draws on the Iron Curtain discursive unconscious to assemble signifiers of Eastern Europeanness, a discourse of place consonant with previous media representations in what Jencks calls the musée imaginaire of history, drawn from a variety of sources (cited in Harvey 1990: 87). As Nelson (1997) puts it, 'as long as realist texts and their popular audiences agree that a set of codes represent external reality, they remain potent' (107). With limited knowledge of 1970s Brno, the audience can accept run-down Scottish social housing and post-industrial wasteland as an acceptable substitute conveying a semiotics of Eastern European-ness.

After a sequence in a shopping arcade, with Czech signage again anchoring Eastern Europe-ness, Prideaux meets his contact in another liminal non-place, an industrial waste ground with a backdrop of shabby warehouses. Another high angle wide shot as they drive off continues the sense of surveillance beneath a panoptic gaze. They drive at night to a cabin in the woods and the Operation Testify ambush. The ambush is staged entirely at night, with a squad of troops, attack dogs and an exploding car. Oldham calls this 'a rare sequence which provides a complete contrast to the dominant aesthetic... a thrilling eruption of action' (2016: 737). The establishing wide shots of the rendezvous area use the height of the trees and careful backlighting to construct a mise-en-scène of cinematic scale, and the backlit chiaroscuro of the 
hazy blue light through the trees during the ambush aspires to the cinematic, emphasising the verticality of the trees and turning their trunks into the bars of a cage as the trap closes on Prideaux. While the novel describes Prideaux's interrogation and transfer between various holding areas, he vanishes from the television serial for the remainder of episode one. Prideaux's fate is suggested by shots of lorries moving through the dark forest: Prideaux exists here as a presence-in-absence, implicitly consumed by the landscape. Devoid of English dialogue, with its few lines subtitled, this sequence requires an attentive cinematic 'gaze' and further complicates assumptions about 1970s television's lack of visual qualities (Ellis 1992). The Testify sequence shows an aspiration to the cinematic in both its scale and its carefully constructed aesthetic, as the forest becomes a cage.

The production's consumption of a Scottish location results in the production team's consumption by place (Urry 1995). Tony Pierce-Roberts recalls:

it should have been shot in Black Park, quite frankly, because it was night, there were fir trees, and frankly, it could have been anywhere and I didn't quite know why they opted to do that because it meant taking lots of gennies ${ }^{6}$ all the way up to Glasgow, it meant taking a very large lantern I used called a Wendy's light into a huge forest, that all had to be rigged up on dimmers and things like that, and of course the weather was appalling, and one of the generators got stuck on the way into the forest so we were delayed for about two days while they pulled it out. (PierceRoberts 2010a)

Black Park, near Pinewood Studios in Buckinghamshire, portrayed Transylvania in many horror films (Pirie 2008) and had an established place-discourse as an old European landscape with menacing Gothic connotations. However, Scotland seems to lend itself well to depicting the Iron Curtain discursive unconscious. Colin McArthur (1982) notes that while Glasgow has a complex cultural identity such as the 'no mean city' discourse of impoverished slums or the left-wing 'Red Clydeside', the city has little prevailing visual place-myth. Glasgow in the 
1970s thus has sufficient 'plasticity of place' (Landman 2009) to substitute for a Soviet industrial town and Czech forest. What is perhaps significant is Scotland's role in the British national imaginary as 'here be dragons' territory (McArthur 2003: 57) with associations of leftwing, urban proletarian masculinity. Substituting for Czechoslovakia as a perilous marginal site, 1970s Glasgow is hazardously peripheral to the London-based BBC drama department, but its use also signifies the production's distinction in being able to travel so far, signalling symbolic capital.

The visual discourses of Eastern Europe are reinforced through the Iron Curtain discursive unconscious deployed in TTSS. MacCannell (1999) observes that places only become 'authentic' once measured against the alias of reproduction, in this case the place-myth discourses circulated in intertexts such as spy films and television. Brno has little abiding placemyth even today. Situated behind the Iron Curtain in 1979, and therefore unfamiliar to British viewers, Brno is represented by a visual iconography involving generalised signifiers of Eastern Europe: roadblocks, watchtowers, run-down social housing, linguistic signifiers, pine forests and liminal wastelands. Demonstrating the way in which such discourses of place are reproduced, Glasgow was again substituted for a Communist city, Moscow, in An Englishman Abroad (BBC 1983) (McKechnie 2007). Visual representations of place are therefore recycled and reinforced through what Urry (2002) calls a 'hermeneutic circle': these Cold War spaces conform to cultural expectations.

\section{Cinematic Margins}

Comparing the cinema version's representation of Eastern Europe complicates assumptions about television and cinema aesthetics. As discussed, television is often assumed to be a 
medium of interior, intimate close-up and detail, while the cinematic is assumed to offer landscape and spectacle, rewarding the attentive 'gaze'. However, the 2011 cinema adaptation presents Prideaux's (Mark Strong) mission with more temporal and geographical compression. The sequence is relocated to Budapest, more recognisable than Brno thanks to Budapest's development for international tourism since the fall of the Iron Curtain. Prideaux's journey is compressed into a montage of establishing shots. The sequence opens with a tourist-friendly wide shot of the Hungarian Parliament building as MiG fighters fly overhead, establishing both geographical locale and the Cold War historical context, supported by Control's (John Hurt) anchoring voice-over 'I want you to go to Budapest'. Four tracking shots of Prideaux and his contact in the street are juxtaposed, with the contact walking left to right and Prideaux walking right to left, conveying their impending convergence within a mise-en-scène of Eastern European language signifiers painted on buildings behind them. A wide shot of the Parisian Court arcade in Budapest city centre is held long enough to show Prideaux's position at a pavement café and place-signifiers of Hungarian language signage and Gothic architecture. This symmetrical composition establishes the arcade as menacing, its walls forming a box framing Prideaux and foreshadowing the imminent ambush. The ambush is confined to a single dramatic site, and relies on a build-up of tension through details such as sweat on a waiter's face, or cups rattling from the vibration of underground trains, rather than the television serial's mimetic realisation of the novel's 'military tattoo'. The cinema version presents this sequence less 'cinematically' in terms of action spectacle than does the television adaptation, demonstrating that essentialising models of television's intimacy and focus on detail are inadequate. In its focus on detail and performance, this sequence turns the arcade into an implicitly un-cinematic, enclosing 'dramatic room'. 
The cinema version is therefore more accessible than the 'explanatory reticence' (Deyo 2017: 5) of the television serial in its depiction of these narrative sites. While David Bordwell suggests that the cinema version's economical establishing shots practice 'suppressive narration' (2012) in comparison with other cinema thrillers, the film is still less subtle with its representation of place than the television serial. The film utilises more overtly touristic signifiers of location such as the wide shot of the Budapest Parliament building, the red London bus, Big Ben, the Eiffel Tower, and the Blue Mosque for the film's Hong Kong substitute Istanbul. In the relative paucity of its visual cues the television serial presents a more obscure construction of Cold War spaces, dependent on close attention from the audience, in the form of a domesticated version of the concentrated cinematic 'gaze'.

\section{Dramatic Rooms and Intimate Screens}

In contrast with the 'cinematic' spectacle of spy thriller action and Lisbon travelogue in the first two episodes, the remainder of the television serial relies largely on dramatic rooms. Joseph Oldham notes the television serial's tension between heritage spaces (Oxford, country houses, hotels) and 'small, cramped, dark and dingy' interiors (2013: 742). The committee rooms and corridors of the Circus, depressing Fleet Street restaurants, faded hotel rooms, and shabby safe houses construct a drab, confining visual discourse of post-imperial 1970s Cold War England. Given its reliance on television's 'dramatic room', then, much of the BBC TTSS might well have fitted into the videotaped electronic studio production paradigm. However, location lends the production's interiors a verisimilitude and atmosphere which three-walled studio sets could not match. For example, in episode three, Smiley visits Connie (Beryl Reid), the Circus' deposed Head of Research, at her home in Oxford. A montage of Smiley amidst Oxford University architecture gives way to the grey, snowy street where Connie lives. Her cramped sitting room with its faded paint and shabby furniture evokes naturalist theatre's 
'room as trap, with the sounds and messages of a determining and frustrating world coming in from outside' (Williams 1968: 318-319). Her small electric fire and Smiley's refusal to remove his coat emphasise the winter weather outside and Connie's exiled status - literally out in the cold. As Smiley leaves, the low camera shows the ceiling, emphasising Connie's confinement. Framed in progressively tightening close-ups, the scene ends on a tight close-up of Connie's face, confirming television's debt to the 'intimate screen'. Similar techniques are used throughout the serial, showing all four walls, constructing a sense of enclosure and adding to the oppressive atmosphere of surveillance and entrapment.

Tony Pierce-Roberts suggests that the use of interior locations makes a distinctive contribution to the mise-en-scène, despite an implied constraint in his account of the way locations framed action and visual composition:

as I should have lit them [i.e. built Ealing film studios sets] the same way as real locations I think the overall look would have been the same. It might have saved some time and given us a little more flexibility in camera movements but I think the decision to shoot in sometimes very claustrophobic rooms was the right one. (Pierce-Roberts 2010b)

The locations also use the fourth wall to convey the novel's paranoid claustrophobia, demonstrating the dialectic between production space and narrative place. Although these locations are interiors, their accretions of detail such as wiring on walls and chipped paint add texture and verisimilitude that sets could not convey:

Tinker Tailor would not have been Tinker Tailor in the studio. [...] Even those interior scenes, what Le Carré in his little language calls the Circus, you know the head of MI6, you would never have got that feeling of decaying Britain, really, of the kind of institutional green paint on the walls [...] Because Tinker Tailor, it sort of lived on its atmosphere. (Powell 2009) 
This atmosphere is reflected in the serial's cinematography. Pierce-Roberts denies any aspiration to the artistic per se: 'I don't consciously try to say, well I want this to look like a painting. I hate that approach' (Pierce-Roberts 2010a). ${ }^{7}$ Nonetheless, there is an aspirational aesthetic at work here, distancing the production from the functional image so often attributed to television. In much of TTSS, deep shadows and high contrasts convey what Lury (1996), in another context, has called a 'tele-noir' style. Noir conventionally offers jaded protagonists caught up in narratives of 'failure, deceit and betrayal' (Dixon 2009: 1) with a stylised aesthetic of dark moody photography. The morally and physically decaying setting of noir functions as 'a literal and figurative zone of darkness, a place that must be illuminated' (3).

Cinematography connects thematic and aesthetic tropes to complement the atmosphere of the television TTSS. For example, episode one's scene with Control (Alexander Knox) and Prideaux is apparently lit from a single desk lamp, casting deep shadows across their haggard faces and suggesting secrets lurking in the dark. When Tarr (Hywel Bennett) is interrogated in episode two, the room is starkly lit from a single overhead source; later, dawn light slanting in the window creates a hazy chiaroscuro reminiscent of the Testify sequence, linking Tarr's story with Prideaux's ambush. In episode five, Smiley and Prideaux talk in Smiley's car at night, their faces limned with a stark key light evoking monochrome's austere, almost literary connotations and aesthetic superiority (Street 2012). And in episode seven, when Guillam waits outside the safe house for the arrival of the mole, the street is lit with a noir-ish key light. Contradicting his earlier disavowal of aspiration, Pierce-Roberts attributes this 'tele-noir' aesthetic to 1970 s cinema:

In terms of the look for Tinker Tailor [...] I was very taken at the time with the Godfather ${ }^{8}$ series and if you look at a lot of the lighting on these it's kind of top light as against the more traditional right in-your-face [fill] light. (Pierce-Roberts 2010a) 
Single-camera filming's capacity for the reverse shot and extension of the rhetoric of the threewalled studio set makes the serial's interiors claustrophobic and oppressive. In the liminal Circus corridors, expressive use is made of cramped interiors: in episode four a convex mirror on the wall seems to observe Guillam en route to his interrogation, the lift's pantographic grille cages him, the lift's narrow confines trap him with his colleagues and the physical proximity builds tension. Guillam is contained within intradiegetic frames of mirrors and cage doors, and the confined space makes for obtrusively close framings of faces, emphasising the scopic regimes implicit in panoptic institutional architecture and the way location space frames production. The unusual shot composition here, with Guillam looking out of frame without the usual 'looking room' organising the frame, adds to the unease. Shooting down the Z-axis of corridors in the Circus constructs an oppressive mise-en-abyme which suggests the labyrinthine bureaucracy of the secret service as well as that of the narrative. The frames-within-frames motif also recalls the matryoshka dolls of the title sequence and the imagery of concealed identities.

\section{Grids and Boxes: The 'Great Game'}

In contrast to the television serial, the 2011 film does not rely on compressing characters into shabby, claustrophobic rooms, but instead turns its more expansive cinematic spaces into grids, constructing space as a series of layered frames to suggest observation and entrapment. Characters are isolated either within intradiegetic frames, behind transparent layers, or both. In shot after shot, characters are framed within grids or behind glass: the Islay hotel window, the internal windows of the Circus, the Budapest arcade windows, the Istanbul harbour building windows, reinforced mesh glass in the garage, the windows of Smiley's house. These shots all make space liminal by dividing it up and placing frames and grids between camera and 
characters, transforming the screen into another version of Bordwell's (2012) checkerboard motif. In Westerby's casino, the panes of the rear window wall divide the view beyond into another grid; overgrown trees visible outside make this site liminal, bringing nature into culture, while also suggesting that the exiled Westerby is in the wilderness. Shots of characters through the windows of cars and caravans emphasise the liminality of these unfixed structures, boxing in the protagonists and recalling the Circus' soundproofed modules. Symmetrical framings compress people into dramatic rooms, such as the Budapest arcade, Lacon's squash court, and the Nursery interrogation cell. Exterior wide shots of architecture divide the screen into further boxes, such as the composite long shots of the Circus archive or the Istanbul hotel exterior, intradiegetic window frames turning the screen into a grid which converts characters into pawns on a chessboard, isolated within discrete but observed, surveilled dramatic rooms.

These layers of transparency blur discrete spaces, connecting inside and outside and confusing clear definitions of place, while reflections in glass over the main action make these sites liminal and heterotopic, emphasising themes of surveillance, instability, identity and threat. In the closing montage, Haydon (Colin Firth) is shot through wire mesh at the Nursery, Tarr (Tom Hardy) is seen behind vertical railings reminiscent of prison bars, and Connie (Kathy Burke) is framed within a sash window, the characters confined by onscreen lines and layers which separate them from the camera and alienate them from the world. The film traps its protagonists by using transparent layers and intradiegetic frames to divide the screen; even expansive cinematic space becomes a cage. Production space, narrative place, and visual style therefore combine to convey the film's central themes of surveillance, betrayal, and entrapment.

\section{Conclusions}


Comparison of the 1979 television serial with the 2011 film has complicated critical orthodoxies about the relative aesthetics of 1970 s television and $21^{\text {st }}$ century cinema. Helen Wheatley has argued that

the aesthetics of spectacle more usually associated with film might equally be associated with certain forms of television; that film and television are both, at times, spectacular, rather than that television is cinematic because of its presentation of spectacle and its various associated visual pleasures. (2016: 7)

The article has demonstrated that the television serial's fidelity to its source novel results at times in a wider canvas and more mimetic spectacular action than equivalent sequences in the cinema version. The television serial employs its cinematography to connect theme, narrative and aesthetic in subtly complex ways, such as frames-within-frames and noirish chiaroscuro. However, the checkerboard motif pervading the 2011 version's mise-en-scène arguably makes it more obviously 'cinematic' than the television serial, in its developed integration of a cage motif as a visual metaphor connecting narrative and aesthetic throughout the production. Notwithstanding the complexity of this motif, the 2011 film is at times more prone to compressing its characters into 'dramatic rooms', turning cinematic space into confining boxes, than the 1979 serial. In its narrative compression and unsubtle use of signifiers of place, the cinema adaptation of TTSS is therefore often less 'cinematic' than the television serial.

\section{References}

Alfredson, Tomas (2011), 'DVD Commentary', Tinker Tailor Soldier Spy [DVD], Studiocanal.

Augé, Marc (1995), Non-places: introduction to an anthropology of supermodernity, London: Verso. 
Barton, Ruth (2008), 'When the Chickens Came Home to Roost: British Thrillers of the 1970s', in: Shail, Robert. ed. Seventies British Cinema, London: BFI/Palgrave Macmillan. pp.46-55.

BBC WAC T65/38/1. Tinker Tailor Soldier Spy 1977-82.

Bignell, Jonathan (2010), 'Transatlantic Spaces: Production, location and style in 1960s1970s action-adventure TV series', Media History, 16 (1) February, pp.53-65.

Bordwell, David (2012), Tinker Tailor: A Guide for the Perplexed, [online] Available at: http://www.davidbordwell.net/blog/2012/01/23/tinker-tailor-a-guide-for-theperplexed/ [Accessed November 23 2012].

Brunsdon, Charlotte (2007a), London in Cinema: The Cinematic City since 1945, London: BFI.

Brunsdon, Charlotte (2007b), 'Towards a History of Empty Spaces', Journal of British Cinema and Television, 4: 2, pp.219-234.

Caughie, John (2000), Television Drama: Realism, modernism and British culture, Oxford: Oxford University Press.

Churchill, Winston (1939), The Russian Enigma, London: BBC, October 1.

Cinema North West (2011), Adaptation 2011: John Irvin interview, October 14-16, Dromohair.

Crowley, D. and Pavitt, J. eds. (2008) Cold War modern: design 1945-1970, London: V\&A. Deyo, Nathaniel (2017), 'Opening Choices: Tinker Tailor Soldier Spy: Significantly ordinary', Movie: A Journal of Film Criticism, 7, pp.4-9.

Dixon, Winston Wheeler (2009), Film Noir and the Cinema of Paranoia, Edinburgh: Edinburgh University Press.

Dovey, Kim (1999), Framing Places: Mediating Power in Built Form, London: Routledge. 
Eaden, James and Renton, David (2002), The Communist Party of Great Britain since 1920, Basingstoke: Palgrave.

Ellis, John (1992), Visible Fictions: Cinema, Television, Video. $2^{\text {nd }}$ ed., London: Routledge. Fisher, Mark (2011), 'The Smiley Factor', Film Quarterly, 65: 2, pp.37-42.

Harvey, David (1990), The Condition of Postmodernity: An Enquiry into the Origins of Cultural Change, Oxford: Blackwell.

Jacobs, Jason (2000), The Intimate Screen: Early British television drama, Oxford: Oxford University Press.

Landman, Jane (2009), “'Not in Kansas Anymore': Transnational Collaboration in Television Science Fiction Production', in Mayer, Vicki, Banks, Miranda J., Caldwell, John T., (eds) Production Studies: Cultural studies of media industries, New York and London: Routledge, pp.140-153.

Lash, Scott and Urry, John (1994), Economies of Signs and Space, London: Sage.

Le Carré, John (2004), 'Interview', Smiley’s People [DVD], BBC Worldwide.

Le Carré, John (1999), Tinker Tailor Soldier Spy [1974], London: Sceptre.

Lury, Karen (1996), 'Television Performance: Being, Acting and 'Corpsing', New Formations, 26, pp.114-127.

MacCannell, Dean (1999), The Tourist: A new theory of the leisure class, London: University of California Press, Ltd.

McArthur, Colin (ed) (1982), Scotch Reels: Scotland in Cinema and Television, London: BFI.

McArthur, Colin (2003), Brigadoon, Braveheart and the Scots: Distortions of Scotland in Hollywood Cinema, London: I. B. Tauris.

McKechnie, Kara (2007), Alan Bennett, Manchester: Manchester University Press. 
Millerson, Gerald (1979), The Technique of Television Production $10^{\text {th }}$ ed., London: Focal Press.

Mills, Brett (2013), 'What does it mean to call television 'cinematic'?', in Jacobs, Jason and Peacock, Steven. eds. Television Aesthetics and Style, London: Bloomsbury Academic, pp.57-66.

Morgan, Eric J. (2016), 'Whores and angels of our striving selves: the cold war films of John le Carre, then and now', Historical Journal of Film, Radio and Television, 36: 1, pp.88-103.

Murphy, Robert (2012), 'Polanski and Skolimowski in 'Swinging London', Journal of British Cinema and Television, 9: 2, pp.214-229.

Nelson, Robin (1997), TV Drama in Transition, Basingstoke: Macmillan Press Ltd.

Nelson, Robin (2007), State of Play: Contemporary 'high-end' TV drama, Manchester: Manchester University Press.

Newland, Paul (2010), 'Introduction: Don't Look Now? British Cinema in the 1970s', in Newland, Paul. ed. Don't Look Now: British Cinema in the 1970s, Bristol: Intellect, pp.9-20.

Nowell-Smith, Geoffrey (2001), 'Cities: Real and Imagined', in: Shiel, Mark. and Fitzmaurice, Tony (eds), Cinema and the City: Film and Urban Societies in a Global Context, Oxford: Blackwell, pp.99-108.

Oldham, Joseph (2013), “'Disappointed romantics': Troubled Heritage in the BBC's John le Carré Adaptations', Journal of British Cinema and Television, 10: 4, pp.727-745. Pierce-Roberts, Tony (2010a), Telephone interview with author, 30 September 2010. Pierce-Roberts, Tony (2010b), Email correspondence with author, 3 October 2010. Pirie, David (2008), A New Heritage of Horror: The English Gothic Cinema, London: I.B. Tauris. 
Powell, Jonathan (2009), Interview with author, 29 October 2009.

Willmetts, Simon and Moran, Christopher (2013), 'Filming Treachery: British Cinema and Television's Fascination with the Cambridge Five', Journal of British Cinema and Television, 10: 1, pp.49-70.

Shields, Rob (1991), Places on the Margin: Alternative Geographies of Modernity, London: Routledge.

Shils, Edward (1975), Center and Periphery: Essays in Macrosociology, University of Chicago Press.

Street, Sarah (2012), Colour Films in Britain: The Negotiation of Innovation 1900-55, Basingstoke: Palgrave Macmillan/BFI.

Urry, John (1995), Consuming Places, London: Routledge.

Urry, John. (2002), The Tourist Gaze $2^{\text {nd }}$ ed, London: Sage.

Wheatley, H. (2005), 'Rooms within Rooms: Upstairs Downstairs and the studio costume drama of the 1970s', in Johnson, Catherine and Turnock, Rob. eds. ITV Cultures: Independent Television over Fifty Years, Maidenhead: McGraw-Hill Education/Open University Press, pp.143-158.

Wheatley, Helen (2016), Spectacular Television: Exploring Televisual Pleasure, London: I B Tauris.

Williams, Raymond (1968), Drama from Ibsen to Brecht, London: Chatto and Windus.

Williams, Raymond (1974), Television: Technology and Cultural Form, London: Fontana.

\footnotetext{
${ }^{1}$ BBC Written Archive Centre: T65/38/1: Tinker, Tailor, Soldier, Spy Producer's File: 13 July 1978.

${ }^{2}$ Le Carré quotes in this paragraph come from an interview on the Tinker Tailor Soldier Spy movie DVD (2011).
} 
${ }^{3}$ At the risk of damning with faint praise - Pierce-Roberts was also responsible for lighting the shots, and therefore is much more than an operator - this description raises interesting questions around the implied distinction between video camera operators and film cameramen. BBC video camera operators, based in Television Centre, were part of the Engineering department and were often seen as functionaries taking orders from a director in the gallery. Discussing tensions between film and video crews, and again paralleling the jealousies within the fictional Circus, Pierce-Roberts told the author: 'we went abroad and they never did [...] And the [crews were] very much in thrall to these chief engineers. Well of course we weren't, so we had a lot more freedom than any of those crews, so they hated us' (2010a). Pierce-Roberts' credit in the serial simply reads 'Photography'.

${ }^{4}$ Similarly, the director of the cinema version, Tomas Alfredson, comments 'the book is like a maze' (Alfredson, cited in Morgan 2016: 95).

${ }^{5}$ A genuine Brno-based pharmaceutical company dating back to the 1950s (www. lachema.cz).

6 i.e. generators.

${ }^{7}$ This seems disingenuous given that Pierce-Roberts was cinematographer on visually lush Merchant Ivory films such as, for example, A Room with a View (1985), Howards End (1992), The Remains of the Day (1993).

${ }^{8}$ The Godfather (1972) and The Godfather Part II (1974) had been released at this time. 